\title{
Biometric study of the width, length and depth of the root trunk groove of human lower second molars
}

\section{Estudo biométrico da largura, comprimento e profundidade da pre-furca dos segundos molares inferiores de humanos}

\author{
Constanza Marin de los RIOS* \\ Francisco Emílio PUSTIGLIONI** \\ Giuseppe Alexandre ROMITO***
}

\begin{abstract}
RIOS, C. M. de los; PUSTIGLIONE, F. E.; ROMiTO, G. A. Biometric study of the width, length and depth of the root trunk groove of human lower second molars. Pesqui Odontol Bras, v. 16, n. 1, p. 26-30, jan./mar. 2002.

One hundred human lower second molars, 51 from the left side and 49 from the right side, extracted due to their poor clinical and radiographic conditions were utilized in this study. Using a Contracer apparatus, the profiles of the buccal and lingual root surfaces of these teeth were traced on a millimeter-scaled paper. The profiles were registered from the cementoenamel junction (CEJ), millimeter by millimeter, up to the entrance of the furcation. The width, length and depth of the root trunk groove, as well as the length of the root trunk, were studied. After statistical analysis $(p<0.05)$ it was possible to conclude that: a) the mean width of the root trunk groove on the buccal surface was $3.6 \mathrm{~mm}$ and, on the lingual surface, $3.3 \mathrm{~mm}$; b) the mean depth of the root trunk groove on the buccal surface was $0.88 \mathrm{~mm}$ and, on the lingual surface, $0.77 \mathrm{~mm}$; c) the mean length of the root trunk groove on the buccal surface was $2.93 \mathrm{~mm}$ and, on the lingual surface, $3.61 \mathrm{~mm}$. The mean length of the root trunk on the buccal surface was $3.09 \mathrm{~mm}$ and, on the lingual surface, $3.91 \mathrm{~mm}(\mathrm{p}<0.025)$. There was a coincidence between the length of the root trunk and that of its groove in $90.2 \%$ of the buccal surfaces of the samples from the left side, and in $77.5 \%$ of the samples from the right side; on the lingual surface, the coincidence occurred in $77.5 \%$ of the teeth from the left side, and on $88.3 \%$ of the teeth from the right side. This work revealed that there is a concavity on the root trunk region of the lower second molar, whose depth and width were greater on the buccal surface and whose length was greater on the lingual surface. The depth of the root trunk groove increased in the apical direction, with maximum depth in the last millimeter of the root trunk. The root trunk was longer on the lingual surface than it was on the buccal surface.
\end{abstract}

UNITERMS: Furcation defects; Dental pulp cavity; Periodontics; Molar.

\section{INTRODUCTION}

Plaque control, which is usually a difficult procedure, is even more so in the furcation area ${ }^{24}$. GHER; VERNINO ${ }^{10}$ (1980) described the anatomy of multi-rooted teeth, and other authors pointed it out as a high-risk factor for periodontal disea$\mathrm{se}^{2,13,15}$ and therapeutic difficulties ${ }^{1}$.

The study of the width and length of the root trunk can reveal important details related to the progression of periodontal disease, its prevention and treatment. An anatomical detail that deserves attention is the flute-shaped depression that can be observed on the buccal and lingual surfaces of human molars. EASLEY; DRENNAN ${ }^{8}$ (1969) and
HEINS; CANTER ${ }^{12}$ (1968) described this anatomical characteristic as a root developmental groove on the root trunk. Other authors depicted it a concavity which belongs to the root trunk of the upper and lower first molars and extends vertically in the direction of the furcation ${ }^{7,18}$. The purpose of this work is to analyze the length of the root trunk, as well as the width, depth and length of the root trunk groove, both on the buccal and lingual surfaces of human lower second molars.

\section{MATERIALS AND METHODS}

One hundred human permanent lower second molars, 49 from the right side and 51 from the left

\footnotetext{
*Professor, Coordinator, Discipline of Periodontics, University of Vale do Itajai and University of the Joinville Region, Brazil. PhD Student, University of Seville, Spain.

**Associate Professor; ***Assistant Professor - Department of Stomatology, Discipline of Periodontics, School of Dentistry, University of São Paulo, Brazil.
} 
RIOS, C. M. de los; PUSTIGLIONE, F. E.; ROMITO, G. A. Biometric study of the width, length and depth of the root trunk groove of human lower second molars. Pesqui Odontol Bras, v. 16, n. 1, p. 26-30, jan./mar. 2002.

side, extracted due to their clinical and radiographic poor conditions (hopeless teeth) were utilized in this study. Teeth that showed sound trunks and absence of fused roots were selected. After extraction, the teeth were immersed in a $2 \%$ sodium hypochlorite solution for 3 hours in order to facilitate the removal of debris.

In order to assess the profile of the root trunk area, records of the buccal and lingual surfaces of all selected teeth were made by means of a Contracer apparatus. Measurements were carried out from the cementoenamel junction to the furcation entrance, millimeter by millimeter.

Starting from a line tangent to the most convex points of the surface profile, the measurement of the depth of the root trunk groove was carried out. The values of the width and depth of the groove were obtained on a millimeter-scaled paper. The values were divided by 20 , which corresponded to the amplification utilized in the Contracer machine.

The statistical analyses employed were the analysis of variance ( $\mathrm{F}$ test) and Tukey's test.

\section{RESULTS}

The width, length and depth of the root trunk groove and the length of the root trunk of lower second molars are shown in Tables 1 to 3 .

The analysis of variance revealed that the values of width, depth and length of the root trunk groove were statistically significant, since the calculated $\mathrm{F}$ values for the three measurements were greater than those of the critical $\mathrm{F}$ (Table 1). The

TABLE 1 - Lower second molars from the right and left sides - width, depth and length $(\mathrm{mm})$ of the root trunk groove. Values of the analysis of variance $(\mathrm{F})$, critical $\mathrm{F}$ and calculated F.

\begin{tabular}{l|c|c|c|c|c|c}
\hline \hline \multirow{2}{*}{$\begin{array}{c}\text { Analysis } \\
\text { of } \\
\text { variance }\end{array}$} & \multicolumn{2}{|c|}{ Width } & \multicolumn{2}{c|}{ Depth } & \multicolumn{2}{c}{ Length } \\
\cline { 2 - 7 } & Buccal & Lingual & Buccal & Lingual & Buccal & Lingual \\
\hline $\mathrm{n}$ & 100 & 100 & 100 & 100 & 100 & 100 \\
\hline Mean & 3.6 & 3.3 & 0.88 & 0.77 & 2.93 & 3.61 \\
\hline $\begin{array}{l}\text { Standard } \\
\text { deviation }\end{array}$ & 0.93 & 0.98 & 0.27 & 0.24 & 0.89 & 0.76 \\
\hline Critical F & \multicolumn{2}{|c|}{5.15} & \multicolumn{2}{|c|}{3.92} & \multicolumn{2}{|c}{5.15} \\
\hline $\begin{array}{l}\text { Calcula- } \\
\text { ted F }\end{array}$ & \multicolumn{2}{|c|}{$12.75^{*}$} & \multicolumn{2}{|c|}{$7.2^{*}$} & \multicolumn{2}{|c}{$38.45^{*}$} \\
\hline & \multicolumn{2}{|c|}{$\mathrm{p}<0.025$} & $\mathrm{p}<0.05$ & $\mathrm{p}<0.025$ \\
\hline \hline
\end{tabular}

*Statistically significant.
TABLE 2 - Average width and depth (mm) of the root trunk groove, according to the position in relation to the cementoenamel junction. Tukey's test for $0 \times 1 \times 2 \times 3 \times$ $4 \times 5$.

\begin{tabular}{c|c|c}
\hline \hline Position & Width & Depth \\
\hline 0 & 2.29 & 0.18 \\
\hline 1 & 3.29 & 0.39 \\
\hline 2 & 3.69 & 0.72 \\
\hline 3 & 3.93 \\
\hline 4 & 3.31 & 1.05 \\
\hline 5 & 3.71 & 1.26 \\
\hline Tukey & 0.23 & 1.33 \\
\hline \hline
\end{tabular}

$\mathrm{p}<0.05$; "]" = statistical difference.

average width of the groove on the buccal surface was $3.6 \mathrm{~mm}$, and, on the lingual surface, $3.3 \mathrm{~mm}$. The average length of the groove on the buccal surface was $2.93 \mathrm{~mm}$ and, on the lingual surface, $3.61 \mathrm{~mm}$. The analysis of variance regarding the values of width demonstrated that, although the values varied from level zero to level five, the differences found were statistically significant only between levels 3 and 4 (Table 2). As for depth, statistically significant differences were found only between levels 4 and 5 (Table 2).

The values of length pertaining to the root trunk (Table 3) were statically significant since the calculated $\mathrm{F}$ values for the three measurements analyzed were greater than those of the critical F. The average length of the root trunk on the buccal surface was $3.09 \mathrm{~mm}$ and, on the lingual surface, $3.91 \mathrm{~mm}$.

Table 4 shows that, on left lower second molars, the length of the root trunk and the length of the root trunk groove were coincident in $90.2 \%$ of the samples on the buccal surface, and in $77.5 \%$ of the samples on the lingual surface. Meanwhile, on the right side, there was coincidence in $77.5 \%$ of the samples on the buccal surface, and in $88.3 \%$ of the samples on the lingual surface.

\section{DISCUSSION}

We did not find in the literature any detailed or scientifically conducted description of the root trunk groove. Some studies simply mention ${ }^{10,11,18}$ this anatomical characteristic. In this research, the registration of data was carried out by means of the Contracer apparatus, which enables high-precision measurements of the concavities and convexities of irregular surfaces. The emplo- 
RIOS, C. M. de los; PUSTIGLIONE, F. E.; ROMITO, G. A. Biometric study of the width, length and depth of the root trunk groove of human lower second molars. Pesqui Odontol Bras, v. 16, n. 1, p. 26-30, jan./mar. 2002.

TABLE 3 - Length of the root trunk ( $\mathrm{mm})$ of lower second molars on the buccal and lingual surfaces. Values of analysis of variance $(\mathrm{F})$, critical $\mathrm{F}$ and calculated $\mathrm{F}$.

\begin{tabular}{l|c|c}
\hline \hline $\begin{array}{c}\text { Analysis of } \\
\text { variance }\end{array}$ & Buccal & Lingual \\
\hline $\mathrm{n}$ & 100 & 100 \\
\hline Mean & 3.09 & 3.91 \\
\hline Standard deviation & 0.9 & 0.68 \\
\hline Critical F & \multicolumn{2}{|c}{5.15} \\
\hline Calculated F & \multicolumn{2}{|c}{$38.76^{*}$} \\
\hline \hline
\end{tabular}

*Statistically significant; $\mathrm{p}<0.025$

yed methodology is efficient due to its precision, speed and facility of execution; therefore, we considered it advantageous in relation to the cross-section technique previously used in other studi$\mathrm{es}^{7,10,11}$.

Although there is no special methodology for the study of root trunk grooves, GHER; VERNINO ${ }^{11}$ (1981) and SVARDSTROM; WENNSTRON ${ }^{18}$ (1988) described a concavity which deepened in the direction of the furcation, starting the measurement at the cementoenamel junction.

GHER; DUNLAP ${ }^{9}$ reported that the beginning of the concavities was found at a distance of $0.7 \mathrm{~mm}$ from the cementoenamel junction on the buccal surface, and at a distance of $0.3 \mathrm{~mm}$ from that junction, on the lingual surface. The concavities progressively deepened until they reached the furcation. However, no evaluation has been carried out on their depth and apical extension'. We noted that the beginning of the root trunk groove occurred on the cementoenamel junction in $77.5 \%$ to $90.2 \%$ of the examined teeth. At the cementoenamel junction, the average depth of the groove was $0.18 \mathrm{~mm}$ and the average width, $2.29 \mathrm{~mm}$. Thus, in our sample, an area of trunk without groove did not exist in the majority of the analyzed teeth, differently from what was observed by the authors mentioned above ${ }^{9}$.

The collected data enabled us to note that, starting from the cementoenamel junction and heading to the furcation, there was a progressive increase in the width and depth of the root trunk groove, which reached their maximum values in the last millimeter of the root trunk. Although the length of the root trunk groove showed a numerical increase, the variation was statistically significant only between levels 4 and 5 . As to the width of the
TABLE 4 - Percentage of coincidence between the length of the root trunk and the length of its groove.

\begin{tabular}{c|c|c|c|c|c}
\hline \hline Surface & Side & Coincident & $\%$ & $\begin{array}{c}\text { Non- } \\
\text { coincident }\end{array}$ & $\%$ \\
\hline \multirow{2}{*}{ Buccal } & Left & 46 & 90.2 & 5 & 9.82 \\
\cline { 2 - 6 } & Right & 38 & 77.5 & 11 & 22.44 \\
\hline \multirow{2}{*}{ Lingual } & Left & 38 & 77.5 & 11 & 22.44 \\
\cline { 2 - 6 } & Right & 45 & 88.3 & 6 & 11.76 \\
\hline \hline
\end{tabular}

root trunk groove, although it progressively increased until the third millimeter of the root trunk length, decreasing between the third and fourth millimeter, there was a statistically significant difference only between levels 3 and 4 .

According to GHER; VERNINO ${ }^{10}$ (1980), the length of the root trunk of the lower second molar is greater and more variable than that of the lower first molar and, according to BAIMA ${ }^{3}$ (1986), the further back the position of the tooth in the dental arch, the greater the length of the root trunk. We were able to make some comparisons with the data obtained by GHER; VERNINO ${ }^{10}$ (1980). These authors affirmed that the length of the root trunk of the lower first molar on the buccal surface was $3 \mathrm{~mm}$ and, on the lingual surface, $4 \mathrm{~mm}$. According to our results, the length of the root trunk of the lower second molar varied from 3 to $5 \mathrm{~mm}$, with an average of $3.09 \mathrm{~mm}$ on the buccal surface and $3.91 \mathrm{~mm}$ on the lingual surface.

Analyzing our results, there was a statistically significant difference between the buccal and lingual surfaces of lower second molars regarding the width and depth of the trunk - those measures were greater on the buccal surface, in $95 \%$ of the cases.

The fact of the root trunk groove being shorter on the buccal surface could be significant considering the greater severity of its exposure on the buccal surface of molars, as it is reported in epidemiological surveys carried out with mandibular teeth $^{19,20,21,22}$, dry mandibules and crania ${ }^{14}$. As it has been discussed by several authors, this greater severity could be related to variations in radicular morphology - the root trunk groove is proportionally larger and deeper on the buccal surface.

We did not find any statistically significant differences between the values obtained for teeth from the left and right sides. Likewise, epidemiological studies carried out with dry mandibules ${ }^{20,22}$ did not 
RIOS, C. M. de los; PUSTIGLIONE, F. E.; ROMITO, G. A. Biometric study of the width, length and depth of the root trunk groove of human lower second molars. Pesqui Odontol Bras, v. 16, n. 1, p. 26-30, jan./mar. 2002.

find any statistical differences between the left and right sides, regarding the severity of periodontal disease.

Clinical works and epidemiological surveys have shown that, when compared with other teeth, molars accumulate more plaque $e^{5,6}$, are more prone to extraction ${ }^{4}$, and show worse prognosis ${ }^{13,16}$. The need for special care to avoid the progression of periodontal disease in molars becomes obvious once we know that there are important predisposing anatomical factors, such as radicular concaviti$\mathrm{es}^{6,10,11}$.

Considering that the root trunk is responsible for a large percentage of the total area of insertion of molars, and taking into account the previously described features of its groove, with regard to the difficulties of treatment and the presence of plaque-retaining recesses, our efforts should be concentrated on the radicular trunk region. We should have a preventive perspective when the periodontal disease is still restricted to the trunk area, with its complicating factor, the root trunk groove. We can thereby prevent the disease from reaching an area of high risk, in apical direction, where the treatment and control of dental plaque by the patient is more difficult and sometimes even impossible.

\section{CONCLUSIONS}

We can conclude that the width of the root trunk groove was, approximately, $3.5 \mathrm{~mm}$ for lower second molars. Therefore, when we probe the root trunk groove and the periodontal pocket depth is grater than $3 \mathrm{~mm}$, we are very close to the furcation entrance; however, we can rarely diagnose it.

\section{ACKNOWLEDGMENTS IN MEMORIAM}

Professor José Cássio Marques Carvalho, supervisor of this work.

Professor Simão Kon, Chairman, Discipline of Periodontics, FOUSP, Brazil.

RIOS, C. M. de Los; PUSTIGLIONE, F. E.; ROMITO, G. A. Estudo biométrico da largura, comprimento e profundidade da pré-furca dos segundos molares inferiores de humanos. Pesqui Odontol Bras, v. 16, n. 1, p. 26-30, jan./mar. 2002.

Foram obtidos 100 dentes, segundos molares inferiores (51 esquerdos e 49 direitos) extraídos de humanos quando diagnosticados como condenados (extração indicada). Por meio de um aparelho Contracer foram traçados, em papel milimetrado, os perfis das faces vestibulares e linguais dos 100 dentes em estudo. Estes perfis foram registrados a partir do limite amelocementário, de milimetro em milímetro, até que atingíssemos a entrada da furca. Foram realizadas medidas da largura, comprimento e profundidade da região da pré-furca, assim como o comprimento do tronco radicular. Após a análise estatística $(\mathrm{p}<0,05)$, conclui-se que: a) a largura da pré-furca, na face vestibular, é de 3,6 mm e na face lingual $3,3 \mathrm{~mm}$; b) a profundidade da pré-furca foi de $0,88 \mathrm{~mm}$ na face vestibular e $0,77 \mathrm{~mm}$ na face lingual; c) o comprimento da pré-furca na face vestibular foi de $2,93 \mathrm{~mm}$ e de $3,61 \mathrm{~mm}$ na face lingual. O comprimento do tronco radicular foi de $3,09 \mathrm{~mm}$ na face vestibular e de $3,91 \mathrm{~mm}$ na face lingual $(\mathrm{p}<0,025)$. Houve uma coincidência do comprimento do tronco radicular e da pré-furca em $90,2 \%$ da amostra para a face vestibular no lado esquerdo e $77,5 \%$ no lado direito; para a face lingual, a coincidência ocorreu em $77,5 \%$ dos casos no lado esquerdo e $88,3 \%$ no lado direito.

UNITERMOS: Defeitos da furca; Cavidade da polpa dentária; Periodontia; Molar.

\section{BIBLIOGRAPHIC REFERENCES}

1. ABDALLAH, F.; KON, S.; RUBEN, M. P. The furcation problem: etiology, diagnosis, therapy and prognosis. $\mathbf{J}$ West Soc Periodontol, v. 35, n. 4, p. 129-142. 1987.

2. AXELSSON, P.; LINDHE, J. Effect of controlled oral hygiene procedures on caries and periodontal disease in adults - results after 6 years. J Clin Periodontol, v. 8, n. 3, p. 239-248, June 1981.

3. BAIMA, R. F. Considerations for furcation treatment. Part I - diagnosis and treatment planning. J Prosthet Dent, v. 56, n. 2, p. 138-142, Aug. 1986.

4. BECKER, W.; BERG, L.; BECKER, B. Untreated periodon- tal disease. A longitudinal study. J Periodontol, v. 50, n. 5, p. 234-244, May 1986.

5. BJORBY, A.; LÖE, H. The relative significance of different local factors in the initiation and development of periodontal inflammation. J Periodontal Res, v. 2, n. 1, p. 76-77, Jan. 1966.

6. BOWER, R. C. Furcation morphology relative to periodontal treatment. Furcation root surface anatomy. J Periodontol, v. 50, n. 7, p. 366-374, July 1979.

7. DUNLAP, R. M.; GHER, M. E. Root surface measurements of the mandibular first molar. J Periodontol, v. 56, n. 4, p. 234-238, Apr. 1985.

8. EASLEY, J. R.; DRENNAN, G. A. Morphological classifica- 
RIOS, C. M. de los; PUSTIGLIONE, F. E.; ROMITO, G. A. Biometric study of the width, length and depth of the root trunk groove of human lower second molars. Pesqui Odontol Bras, v. 16, n. 1, p. 26-30, jan./mar. 2002.

tion of the furca. J Can Dent Assoc, v. 35, n. 2, p. 104-107, Feb. 1969.

9. GHER, M. E.; DUNLAP, R. W. Linear variation of the surface area of the maxillary first molar. J Periodontol, v. 1, n. 56, p. 39-43, Jan. 1985.

10. GHER, M. E.; VERNINO, A. R. Root morphology - clinical significance in the pathogenesis and treatment of periodontal disease. J Am Dent Assoc, v. 101, n. 4, p. 627-633, Oct. 1980.

11. GHER, M. E.; VERNINO, A. R. Root anatomy. A local factor in inflammatory periodontal disease. Int J Periodontics Restorative Dent, v. 1, n. 5, p. 53-63, Sept./Oct. 1981.

12. HEINS, P. J.; CANTER, S. R. The furca involvement: a classification of bony deformities. Periodontics, v. 6, n. 2, p. 84-86, Apr. 1968.

13. HIRSCHFELD, L.; WASSERMAN, D. A long-term survey of tooth loss in 600 treated periodontal patients. J Periodontol, v. 49, n. 5, p. 225-237, May 1978.

14. LARATO, D. C. Furcation involvements: incidence and distribution. J Periodontol, v. 41, n. 9, p. 449-501, Sept. 1970.

15. LÖE, H.; ANERUD, A.; BOYSEN, H.; SMITH, M. The natural history of periodontal disease in man - the rate of periodontal destruction before 40 years of age. J Periodontol, v. 49, n. 12, p. 607-620, Dec. 1978.

16. McFALL, W. T. Tooth loss in 100 treated patients with periodontal disease - a long-term study. J Periodontol, v. 53, n. 9, p. 539-549, Sept. 1982.

17. PHILSTROM, B. L.; OLIPHANT, T. H.; HUGH, R. B. Molar and non-molar teeth compared over $6 \frac{1}{2}$ years following two methods of periodontal therapy. J Periodontol, v. 55, n. 9, p. 499-504, Sept. 1984.

18. SVÄRDSTRÖM, G.; WENNSTRÖM, J. L. Furcation topography of the maxillary and mandibular first molars. $\mathbf{J}$ Clin Periodontol, v. 15. n. 5, p. 271-275, May 1988.

19. TAL, H. Furcal defects in dry mandibules of South African negroes. Prevalence and distribution. J Dent Assoc $\mathbf{S}$ Afr, v. 36, n. 8, p. 623-627, Aug. 1981.

20. TAL, H. Furcation defects in dry mandibules. Part I - a biometric study. J Periodontol, v. 53, n. 6, p. 36-43, June 1982.

21. TAL, H. Relationship between the depths of furcal defects and alveolar bone loss. J Periodontol, v. 53, n. 10, p. 631-634, Oct. 1982.

22. TAL, H.; LEMMER, J. Furcal defects in dry mandibules. Part II. Severity of furcal defects. J Periodontol, v. 53, n. 6, p. 364-367, June 1982.

23. WAERHAUG, J. Presence or absence of plaque on subgingival restorations. Scand J Dent Res, v. 83, n. 4, p. 193-201, July 1975.

24. WAERHAUG, J. The furcation problem: etiology, pathology, diagnosis, therapy and prognosis. J Clin Periodontol, v. 7, n. 12, p. 73-95, Apr. 1980.

\section{Scientific Electronic Library Online

SciELO - Scientific Electronic Library Online é uma coleção eletrônica de revistas científicas disponíveis na Internet. A coleção traz os textos completos de artigos científicos, bases de dados e relatórios de uso e de impacto da literatura científica publicada no site.

Em operação desde 1997, atualmente estão disponíveis 29 revistas brasileiras nas áreas de ciências biológicas e da saúde, ciências sociais e humanas, ciências agrárias, física etc. Novas publicações são incluídas regularmente em várias especialidades.

Entre as revistas de nossa coleção, está a Pesquisa Odontológica Brasileira.

\section{Consulte a Pesquisa Odontológica Brasileira (Revista de Odontologia da USP) na SciELO - http://wwww.scielo.br/rousp}

